\title{
A Novel Approach to Inhibit HIV-1 Infection by Actively Neutralizing the Antibodies of Reverse Transcriptase System
}

\author{
Sherif Salah ${ }^{1 *}$, Bassam Hajjar ${ }^{2}$ and Reham Essam ${ }^{3}$ \\ ${ }^{1}$ Department of Clinical Immunology, Faculty of Medicine, Cairo University, Egypt \\ 2 Department of Gastroenterology/Hepatology, University of Damascus, Syria \\ ${ }^{3}$ Faculty of Pharmacy, Cairo University, Egypt
}

*Corresponding author: Sherif Salah, Department of Clinical Immunology, Faculty of Medicine, Cairo University, Egypt, Tel: 00201005218981; E-mail: sherif65@usa.com

Copyright: $\odot 2014$ Salah S, et al. This is an open-access article distributed under the terms of the Creative Commons Attribution License, which permits unrestricted use, distribution, and reproduction in any medium, provided the original author and source are credited.

Received date: February 19, 2014; Accepted date: May 20, 2014; Published date: May 31, 2014

\begin{abstract}
This study introduces a new approach for HIV eradication based on a new enzyme combination (reverse transcriptase and DNA polymerase) formula for inhibiting and/or preventing this disease. The pilot study was done on ten patients who were all positive for HIV antibodies, and were never treated with antiretroviral medications. Those patients were registered under surveillance by HIVIAIDS Control Department at the Egyptian Ministry of Health (MOH). All of these patients have the same clinical symptoms of HIVIAIDS and consented to take this combination therapy in the form of subcutaneous injection of $0.1 \mathrm{cc}$ twice daily for 24 weeks. At the end of therapeutic protocol, all of the patients' viral loads were undetectable (less than 16 copies $/ \mathrm{ml}$ ); also there was a significant increase in their CD4 cells counts to over 500 cells/ $\mu \mathrm{L}$. According to these findings, this treatment protocol may be promising therapeutic modality for treating HIV-1 infection causing Acquired Immunodeficiency Syndrome (AIDS).
\end{abstract}

Keywords: HIV; Reverse transcriptase; DNA polymerase

\section{Introduction}

HIV/AIDS is not only a public health problem but also a social, political and economic challenge. The key concern with HIV infection is not only about infected person, but also about the chain of people infected by that individual and those he or she will probably infect in the future. By the end of the year 2012, 35.3 million people were living with HIV worldwide. Among them, 2.3 million people were newly infected. The estimated HIV related deaths during 2012 were around 1.6 million people; approximately $68 \%$ of the living cases are in the sub-Saharan Africa, where the majority of epidemic occurs [1]. In Egypt, where this study is conducted, the prevalence of newly diagnosed HIV positive patients is relatively high. Therefore, Egypt is considered to be one of the regions of the world with rising HIV infection rate [2].

The virus is transmitted in $71 \%$ of the cases sexually, with heterosexual contact comprising almost half of all detected cases [3] Intravenous drug use and blood transfusion each accounts for $9 \%$ of the detected cases, while the percentage of transmission through renal dialysis and unknown modes comprises the rest [4].

HIV is a retrovirus that infects the human immune system; Reverse transcriptase enzyme is an essential part of the virus that reads the sequences of viral RNA that have entered the host cell and transcribes the sequences into complementary DNA sequences [5]. This means that without reverse transcriptase, the viral genome could not incorporate into the host cells, and therefore, could not reproduce.

DNA polymerase enzyme is a vital enzyme for the regulation of multiple physiological cellular functions such as DNA repair, gene transcriptions, cell cycle progression, cell death, chromatin function, and genomic stability [6]. This enzyme is essential for the process of viral replication and the production of a new virion, which also leads us to consider it as a useful tool for the treatment of HIV infections [7].

In this study, we report a generation of cross reactive antibodies inhibiting the reverse transcriptase (RT) of human immunodeficiency virus type-1(HIV-1) in the serum of clinically diagnosed patients repeatedly injected with our combination of AMV reverse transcriptase and DNA polymerase.

\section{Materials and Methods}

Ten patients, all of them were positive for HIV antibodies and confirmed by (HIV-RNA-PCR) The viral loads of all patients were more than 1000 copies/ml by HIV-RNA-PCR, with CD4+T-cell counts of less than 250 cells/ $\mu \mathrm{L}$ Five patients signed their consent to take the combination therapy (test group) while the remaining five patients only contributed to the study via blood sampling without taking the combination therapy (control group). The test groups were given the combination therapy ( Taq DNA polymerase $+A M V$ reverse transcriptase) [Promega Corporation Manufactured], in the form of subcutaneous injections of $0.1 \mathrm{cc}$ twice daily for 24 weeks. The age, sex and immunological tests of all patients are summarized in Table 1.

\begin{tabular}{|l|l|l|l|l|l|l|}
\hline $\begin{array}{l}\text { Patient } \\
\text { number }\end{array}$ & Sex & Age & $\begin{array}{l}\text { CD4+ } \\
(\text { cells/ } \mu \text { I)* }\end{array}$ & $\begin{array}{l}\text { Viral load } \\
\text { (copies/ } \\
\text { ml) }\end{array}$ & ALT (IU/L)** & AST (IU/L)*** \\
\hline 1 & M & 24 & 270 & 92,000 & 67 & 60 \\
\hline 2 & M & 26 & 315 & 105,000 & 33 & 22 \\
\hline 3 & F & 34 & 180 & 447,300 & 67 & 37 \\
\hline
\end{tabular}




\begin{tabular}{|c|c|c|c|c|c|c|}
\hline 4 & $\mathrm{~F}$ & 23 & 170 & 4,300 & 34 & 40 \\
\hline 5 & M & 38 & 150 & 315,000 & 29 & 31 \\
\hline 6 & $M$ & 22 & 340 & 367,000 & 19 & 23 \\
\hline 7 & $M$ & 28 & 403 & 4,000 & 22 & 29 \\
\hline 8 & $M$ & 27 & 178 & 34,000 & 34 & 26 \\
\hline 9 & $\mathrm{~F}$ & 8 & 349 & 1,900 & 16 & 23 \\
\hline 10 & $\mathrm{~F}$ & 6 & 213 & 24,000 & 19 & 16 \\
\hline \multicolumn{7}{|c|}{$\begin{array}{l}{ }^{*} \mathrm{CD} 4+\text { normal range: } 350 \text { to } 550 \text { cells/ } / \mathrm{l} \\
{ }^{* *} \text { ALT normal range: } 0 \text { to } 40 \mathrm{IU} / \mathrm{L} \\
{ }^{* * *} \text { AST normal range: } 0 \text { to } 40 \mathrm{IU} / \mathrm{L}\end{array}$} \\
\hline
\end{tabular}

Table 1: Patient Serology before Treatment with Subcutaneous (Taq DNA polymerase + AMV Reverse Transcriptase.

The clinical pictures of all patients in test and control groups are summarized in Table 2

\begin{tabular}{|l|l|}
\hline $\begin{array}{l}\text { Patient } \\
\text { number }\end{array}$ & Clinical Picture \\
\hline 1 & $\begin{array}{l}\text { Fever, diarrhea, joint pain, muscle ache, general weakness, } \\
\text { moniliasis and HIV-related skin manifestations }\end{array}$ \\
\hline 2 & Fever, diarrhea, abdominal pain, weight loss and a sore throat \\
\hline 3 & $\begin{array}{l}\text { Intermittent fever, chronic diarrhea, significant weight loss, joint } \\
\text { pain, muscle aches, chills, and lymphadenopathy }\end{array}$ \\
\hline 4 & Low grade fever, mild diarrhea, and oral candidiasis \\
\hline 5 & $\begin{array}{l}\text { Mild fever, intermittent diarrhea, right upper quadrant abdominal } \\
\text { pain, nausea, anorexia, significant weight loss, general weakness, } \\
\text { and lymphadenopathy }\end{array}$ \\
\hline 6 & Lymphadenopathy, genital ulcers, chills and fatigue \\
\hline 7 & Joint pain ,headache, muscle aches and mild night fever \\
\hline 8 & Fatigue, muscle pain \\
\hline 9 & Weight loss, anorexia. abdominal pain and tonsillitis \\
\hline 10 & Muscle ache, diarrhea and weight loss \\
\hline
\end{tabular}

Table 2: Patient Clinical Presentation before Treatment with Subcutaneous (Taq DNA polymerase + AMV Reverse Transcriptase.

\section{Serological testing}

Five samples were collected from the treated patients as (test group), and another five samples for patients who did not take the combination (control group) but all of them were positive for HIV antibodies and confirmed by (HIV-RNA-PCR).

\section{Detection of monoclonal antibodies activity}

ELISA plate (Costar 3690), each well was coated with $50 \mu \mathrm{l}$ of 1 $\mu \mathrm{g} / \mathrm{ml}$ recombinant RT. Serum samples for both groups were collected during 6,12,18 and 24 weeks of the study, and each serum sample was diluted with PBS buffer solution as follows $1 / 20,1 / 40,1 / 80$ and $1 / 160 \ldots$ etc. $100 \mu$ was added to the coated wells and incubated for 60 minutes, the anti-RT IgG bound were allowed to react with affinity-purified and alkaline phosphatase-conjugated goat anti-mouse IgG antibodies for 60 minutes, addition of substrate, $\mathrm{p}$-nitrophenylphosphate and waiting for 30 minutes, for color developer and tested for the presence of IgG antibodies to RT.

The absorbance at $410 \mathrm{~nm}$ was measured with an EIA auto reader. Neutralization antibody titer activity was defined as any serum giving a significant increase over $1 / 40$ dilution yielding an absorbance of approximately more than 1.0 after incubation for $30 \mathrm{~min}$ at room temperature, positive and negative reactions in serum diluted to $1 / 20$ yielded an absorbance of less than 0.05 .

\section{Inhibition of HIV-1 RT biological activity}

Serum samples of test group were evaluated for their mAbs ability to inhibit HIV-1 as follows: firstly we incubated serial diluted samples $(1 / 10,1 / 100$ and $1 / 1000)$ of this group with $200 \mu$ l serum samples of the control group in sterile closed glass tubes for 60 minutes at room temperature.

Specific mAbs to HIV-1 RT (Pharmacia Biotech diagnostic) serial dilutions $(1 / 10,1 / 100$ and1/1000) was incubated with serum samples of the control group for one hour under the same conditions as the previous.

\section{Results}

After 24 weeks from the beginning of the therapy, the immunological testing of the above patients were repeated, showing surprisingly undetectable viremia (reference range $<16$ copies $/ \mathrm{ml}$ ) for all the patients with significant elevation in CD4+ T-lymphocytes above 500 cells $/ \mathrm{ml}$ (Table 3). The most important finding of great immunological value is that HIV antibodies by enzyme-linked immunosorbent assay (ELISA) testing were negatives also, the patients reported a significant improvement of their clinical picture (Table 4), the physical activities and the constitutional symptoms of HIV infection (AIDS) including malaise, fatigue, weight loss and joint pain were also improved. There were no significant adverse drug reactions.

There were serological reports concerning the effect of treating with the combination therapy in the formation of neutralizing $\mathrm{mAbs}$ to AMV RT enzyme during 6, 12, 18 and 24 weeks, a high level of IgG anti HIV-1 RT was detected between over $1 / 40$ and1/320 in all serum samples of test group yielding an absorbance over 2.0, while in control group all of them gave absorbance less than 0.1 , except two samples which gave reading equivocal around 1/20.

A successful test of the hypothesis was demonstrated through examining and comparing the results of (HIV-RNA-PCR), for the contents in the test group tubes and the contents in the tubes of specific mAbs to HIV-1 RT. The reports show that tubes of test group with dilution over $1 / 1000$ gives HIV-1 counts by (HIV-RNA-PCR) between $200-1000$ copies/ $\mathrm{ml}$ and the dilution from $1 / 10$ to $1 / 1000$ give completely undetectable HIV copies, while the samples of control group with the specific mAbs to HIV-RT give detectable HIV-1 copies in all dilutions, it appears that the amount of neutralization mAbs in serum samples of treated group has great inhibitory effects to both HIV-1 and RT enzyme activity. Further research is needed to determine if the cross-reactive unspecified neutralizing antibodies is the main agent in inhibition and autolysis of HIV-1 or it acts as a trigger for some complement factors in the serum that accelerate the process of HIV-1 eradication. This recent finding supports the failure 
Page 3 of 4

of our neutralizing Abs in serum of chronic infected patients with HIV to overcome the long standing viral infection.

\begin{tabular}{|c|c|c|c|c|}
\hline $\begin{array}{l}\text { Patient } \\
\text { number }\end{array}$ & $\begin{array}{l}\text { CD4+ } \\
\text { (cells/ } /)^{*}\end{array}$ & $\begin{array}{l}\text { Viral load } \\
\text { (copies/ml) }\end{array}$ & ALT $(\mathrm{IU} / \mathrm{L})^{\star *}$ & AST (IU/L) $)^{\star \star *}$ \\
\hline 1 & 780 & $<16$ & 23 & 38 \\
\hline 2 & 567 & $<16$ & 33 & 35 \\
\hline 3 & 467 & $<16$ & 44 & 47 \\
\hline 4 & 904 & $<16$ & 18 & 40 \\
\hline 5 & 631 & $<16$ & 28 & 31 \\
\hline $\begin{array}{l}{ }^{*} \text { CD } 4+n \\
{ }^{* *} \text { ALT nc } \\
\text { *** AST } n\end{array}$ & $\begin{array}{l}\text { nal range: } 35 \\
\text { al range: } 0 \text { to } \\
\text { nal range: } 0\end{array}$ & $\begin{array}{l}550 \text { cells } / \mu \mathrm{l} \\
\mathrm{IU} / \mathrm{L} \\
0 \mathrm{IU} / \mathrm{L}\end{array}$ & & \\
\hline
\end{tabular}

Table 3: Patient Serology after Ttreatment with subcutaneous (Taq DNA polymerase + AMV Reverse Transcriptase.

\begin{tabular}{|l|l|}
\hline $\begin{array}{l}\text { Patient } \\
\text { number }\end{array}$ & Clinical Picture \\
\hline 1 & Significant decrease in malaise, fatigue and joint pain \\
\hline 2 & Weight gain, no diarrhea \\
\hline 3 & Weight gain, no glands swollen \\
\hline 4 & No fever, weight gain \\
\hline 5 & $\begin{array}{l}\text { Increase in physical and mental conditions, weight gain and } \\
\text { disappearance of body fatigue }\end{array}$ \\
\hline
\end{tabular}

Table 4: Patient Clinical Presentation after treatment with subcutaneous (Taq DNA polymerase + AMV Reverse Transcriptase.

\section{Discussion}

At the present time, the most successful available treatment for HIV is reverse-transcriptase inhibitors [for example azidothymidine $(\mathrm{AZT})]$ and protease inhibitors $[8,9]$.

Our data suggests that the stimulation of the production of enhancing cross-reactive neutralizing antibodies may be important in eradication of HIV-1 infection. Although HIV-1 infection induces neutralizing antibodies, it does not achieve effective protection for chronic patients with HIV-1. Accordingly, the question that arises is why does our immune system not able to stop the consumption of the immune cells while the virus can? Furthermore, why does the viral replication process have a continuous dynamic action with no signs of immune suppression? The answer depends on our vision of the HIV strategy. The HIV stimulates the cytotoxic CD8+ T-cells to act on CD4+ T-cell, and the latter cell will try to inhibit this mechanism. Such a phenomenon could be considered a defensive mechanism, but as long as this process continues and the inhibitors mechanism is gradually depleted, it will lead to a profound destruction of all CD4+ T-cells paving the way to the spread of the viral invasion. Thus, we assume that the failure of immune cells to stop the viral replication mainly comes from the mystery stored in the functions of the RT enzyme that makes our immune cells compatible with its orders [10]. In this study, we used the components of AMV - RT and DNA polymerase enzymes as immunogens to stimulate the formation of neutralizing mAbs to AMV -RT. The results described in this study support our hypothesis and extend the possibility that this treating method may be generally applicable to the generation of enzymeinhibiting serum antibodies and the production of mAbs capable of inhibiting enzyme activity. Such mAbs, once produced, would become a powerful tool for characterizing the structure and function relationship of the enzyme, and revealing unknown epitopes or structures important to its enzyme activity. Many groups have successfully produced monoclonal antibodies to HIV-1 RT although most of the mAbs were ineffective in neutralizing the polymerase activity of RT.

This study introduces a new strategy for HIV (AIDS) cure differing from all remedial methods which depend on treating the viral infection by immune inhibitors for the viral replicating materials reverse transcriptase, DNA. The recent trend of treating HIV/AIDS is to combine at least three drugs from two different classes. These classes include: Non-nucleoside reverse transcriptase inhibitors (NNRTIs), nucleoside reverse transcriptase inhibitors (NRTIs) [11,12] protease inhibitors (PIs), fusion inhibitors and integrase inhibitor. They generally work by disabling the formation of proteins needed by the virus to copy itself (NNRTIs, PIs and integrase inhibitors) or blocks the HIVs entry into the CD4 cells (fusion inhibitors). The side effects of these drugs are remarkable, their lifelong use never leads to complete cure, but it helps to ameliorate the clinical picture, to increase the CD4 cell count and decrease the viral load. While the strategy of our combination is to block HIV copying by direct interference through the drug action, our hypothesis aims to enhance the immune system of the patient to build its own neutralizing antibodies against the virus.

This study and its promising results could be a step towards a real solution for a global problem. However, we have to admit that there was a limitation concerning our study due to the small sample size which emerged from the limited infected cases of HIV/AIDS within reach in Cairo. In addition, the restricted budget that was available also presented challenges, so we emphasize that a further extended and tedious study is needed to evaluate the benefits and values of our novel compound.

\section{References}

1. Purcell DW, Johnson CH, Lansky A, Prejean J, Stein R, et al. (2012) Estimating the population size of men who have sex with men in the United States to obtain HIV and syphilis rates. Open AIDS J 6: 98-107.

2. Talaat M, Kandeel A, Rasslan O, Hajjeh R, Hallaj Z, et al. (2006) Evolution of infection control in Egypt: achievements and challenges. Am J Infect Control 34: 193-200.

3. Ali F, Aziz AA, Helmy MF, Mobdy AA, Darwish M (1996) Prevalence of certain sexually transmitted diseases in Egypt. J Egypt Public Health Assoc 71: 553-575.

4. El Sayed NM, Gomatos PJ, Beck-Sagué CM, Dietrich U, von Briesen H, et al. (2000) Epidemic transmission of human immunodeficiency virus in renal dialysis centers in Egypt. J Infect Dis 181: 91-97.

5. Jaeger J, Restle T, Steitz TA (1998) The structure of HIV-1 reverse transcriptase complexed with an RNA pseudoknot inhibitor. EMBO J 17: 4535-4542.

6. Alt A, Lammens K, Chiocchini C, Lammens A, Pieck JC, et al. (2007) Bypass of DNA lesions generated during anticancer treatment with cisplatin by DNA polymerase eta. Science 318: 967-970.

7. Aldinucci A, Gerlini G, Fossati S, Cipriani G, Ballerini C, et al. (2007) A key role for poly(ADP-ribose) polymerase-1 activity during human dendritic cell maturation. J Immunol 179: 305-312. 
Citation: Salah S, Hajjar B, Essam R (2014) A Novel Approach to Inhibit HIV-1 Infection by Actively Neutralizing the Antibodies of Reverse Transcriptase System. J AIDS Clin Res 5: 310. doi:10.4172/2155-6113.1000310

Page 4 of 4

8. Baeten J (2011) Antiretroviral pre-exposure prophylaxis for HIV-1 prevention among heterosexual African men and women: the Partners PrEP Study. Abstract presented at: Sixth IAS Conference on HIV Pathogenesis, Treatment, and Prevention. Rome, Italy.

9. Thompson MA, Aberg JA, Cahn P, Montaner JS, Rizzardini G, et al. (2010) Antiretroviral treatment of adult HIV infection: 2010 recommendations of the International AIDS Society-USA panel. JAMA 304: 321-333.

10. Sherif Salah, Bassam Hajjar, Reham Essam (2013) A novel approach to inhibiting human immune deficiency virus (HIV-1) infection by actively neutralizing the antibodies of reverse transcriptase system. Journal of AIDS and HIV Research 5: 170-172.

11. Andries K, Azijn H, Thielemans T, Ludovici D, Kukla M, et al. (2004) TMC125, a novel next-generation nonnucleoside reverse transcriptase inhibitor active against nonnucleoside reverse transcriptase inhibitor-resistant human immunodeficiency virus type 1.Antimicrob Agents Chemother 48: 4680-4686.

12. Bacheler L, Jeffrey S, Hanna G, D'Aquila R, Wallace L, et al. (2001) Genotypic correlates of phenotypic resistance to efavirenz in virus isolates from patients failing nonnucleoside reverse transcriptase inhibitor therapy. J Virol 75: 4999-5008. 